\title{
Plasma concentration of atrial natriuretic peptide in spontaneous atrioventricular re-entrant tachycardias of childhood
}

\author{
M Burch, J A Till, M L Rigby, E A Shinebourne, N D Carter, S Jeffery, A Smith
}

\begin{abstract}
Plasma atrial natriuretic peptide was measured in 13 children between the ages of 1 week and 2 years 9 months during atrioventricular re-entrant tachycardia and 15 minutes after the restoration of sinus rhythm. There was a significant decline in atrial natriuretic peptide during sinus rhythm. Plasma concentrations of the peptide were significantly higher during tachycardia in seven infants under 1 year than in the six older children. The heart rates and the duration of tachycardia were not significantly different in the two age groups. Cardiac failure was present in five of seven children under 18 weeks of age during tachycardia but in none of the older children. The plasma concentration of atrial natriuretic peptide did not significantly correlate with duration of tachycardia or heart rate. If tachycardia occurs in young infants the low functional reserve capacity of the developing heart leads to cardiac failure more frequently and it is likely that this was the cause of the significantly higher plasma concentration of atrial natriuretic peptide in the younger children.
\end{abstract}

Atrial natriuretic peptide, a 28 amino acid peptide, is released from the atria in response to distension. ${ }^{12}$ Plasma concentrations of atrial natriuretic peptide were increased during supraventricular ${ }^{3-5}$ and ventricular ${ }^{36}$ tachycardia in adults, probably because of increased atrial tension. ${ }^{78}$ The increased plasma concentration during tachycardia caused diuresis and natriuresis by increasing the glomerular filtration rate and decreasing aldosterone secretion. ${ }^{8}$ We are not aware of any studies on plasma atrial natriuretic peptide during tachycardias in children. The physiological response of the developing heart to tachycardia differs from that of adults ${ }^{910}$ and cardiac failure is a more common accompaniment. ${ }^{11}$ We tested the hypothesis that atrial natriuretic peptide release in response to tachycardia in infants also differed from that in older children by measuring plasma concentration during tachycardia and 15 minutes after restoration of sinus rhythm in 13 patients (age range 1 week to 2 years 9 months). We hoped to define further which factors were the most important in causing release of the peptide during tachycardia.

\begin{tabular}{|c|c|c|c|c|}
\hline Case & Age & $\begin{array}{l}\text { Heart } \\
\text { rate in } \\
\text { tachycardia } \\
\text { (beats/min) }\end{array}$ & $\begin{array}{l}\text { Duration of } \\
\text { tachycardia }\end{array}$ & $\begin{array}{l}\text { Dose of } \\
\text { adenosine } \\
\text { (mg/kg) }\end{array}$ \\
\hline $\begin{array}{r}1 \\
2 \\
3 \\
4 \\
5 \\
6 \\
7 \\
8 \\
9 \\
10 \\
11 \\
12 \\
13\end{array}$ & $\begin{array}{l}1 \mathrm{wk} \\
2 \mathrm{wk} \\
2 \mathrm{wk} \\
7 \mathrm{wk} \\
8 \mathrm{wk} \\
16 \mathrm{wk} \\
17 \mathrm{wk} \\
12 \mathrm{mnth} \\
13 \mathrm{mnth} \\
20 \mathrm{mnth} \\
24 \mathrm{mnth} \\
28 \mathrm{mnth} \\
33 \mathrm{mnth}\end{array}$ & $\begin{array}{l}280 \\
300 \\
300 \\
250 \\
290 \\
300 \\
240 \\
240 \\
260 \\
280 \\
300 \\
270 \\
270\end{array}$ & $\begin{array}{c}6 \mathrm{~h} \\
24 \mathrm{~h} \\
8 \mathrm{~h} \\
5 \text { days } \\
24 \mathrm{~h} \\
2 \text { days } \\
1 \mathrm{~h} \\
2 \mathrm{~h} \\
10 \mathrm{~min} \\
6 \mathrm{~h} \\
12 \mathrm{~h} \\
3 \mathrm{~h} \\
4 \mathrm{~h}\end{array}$ & $\begin{array}{l}0 \cdot 1 \\
0 \cdot 2 \\
0 \cdot 25 \\
0 \cdot 3 \\
0 \cdot 2 \\
0 \cdot 3 \\
0 \cdot 3 \\
0 \cdot 3 \\
0 \cdot 1 \\
0 \cdot 15 \\
0 \cdot 15 \\
0 \cdot 1 \\
0 \cdot 1\end{array}$ \\
\hline
\end{tabular}

\section{Patients and methods}

PATIENTS

The table shows data on the patients. Patients 2 to 6 were in heart failure when blood samples were taken. Patient 9 had undergone Mustard's repair for transposition of the great arteries. Patient 12 had Fallot's tetralogy but had not undergone surgery. The other patients all had normal intracardiac anatomy. All patients presented with atrioventricular re-entrant tachycardias.

\section{METHODS}

In young infants the onset of tachycardia was taken as the time when the child was first noted to be unwell with breathlessness and poor feeding. In older children it was taken from the time of complaint of feeling unwell. In the postoperative patient the tachycardia was noted while the patient was being monitored in the intensive care unit. In all patients echocardiography was performed to assess intracardiac anatomy. The presence of hepatomegaly or a raised jugular venous pressure was taken to indicate cardiac failure. Each patient was examined by two clinicians. Blood pressure and respiratory rate were measured during tachycardia and after restoration of sinus rhythm. The heart rate was calculated from the $R R$ interval on the electrocardiogram.

The blood samples $(1 \mathrm{ml})$ were taken during tachycardia when the peripheral venous line was placed. A further blood sample $(1 \mathrm{ml})$ was taken from the line (after removal of an adequate dead space) 15 minutes after the restoration of sinus rhythm. In view of the age of the patients, sampling was restricted to these occasions. The samples were collected into tubes containing ethylenediamine- 
tetraacetic acid at $1 \mathrm{mg} / \mathrm{ml}$ and aprotinin at 1000 kallikrein inactivator units $/ \mathrm{ml}$. They were placed on ice and immediately centrifuged. The plasma was withdrawn and frozen at $-70^{\circ} \mathrm{C}$.

Atrial natriuretic peptide was extracted from $0.5 \mathrm{ml}$ of plasma using a $\mathrm{C}_{8}$ reverse phase cartridge (Amersham, UK) according to the method developed by Amersham. Mean (SD) recovery of ${ }^{125} \mathrm{I}$-peptide added to plasma was $87(3) \%(n=10)$. Atrial natriuretic peptide concentrations were by radioimmunoassay with a combination of rabbit antiserum generated against human 1-28 atrial natriuretic peptide (Peninsula Laboratories, St Helens) and ${ }^{125} I$-labelled human atrial natriuretic peptide $(2000 \mathrm{Ci} / \mathrm{mmol}$, Amersham, UK) as the tracer. ${ }^{12}$ To cope with the small sample volumes available from paediatric patients, plasma extracts were reconstituted in $0.25 \mathrm{ml}$ of assay buffer and assayed in triplicate by a low volume disequilibrated assay: $50 \mu \mathrm{l}$ of antibody was incubated with $50 \mu \mathrm{l}$ of standard $(0.5-50 \mathrm{pg} /$ tube) or extract for 24 hours at $4^{\circ} \mathrm{C}$. Tracer peptide was then added (approximately $6000 \mathrm{cpm}$ ) and the mixture incubated for a further 24 hours at $4^{\circ} \mathrm{C}$. Free and bound tracer were separated by the addition of $100 \mu \mathrm{l}$ of a 1:20 dilution of donkey antirabbit antiserum containing $0.5 \%$ normal rabbit serum (Guildhay Ltd, Guildford) followed by an overnight incubation at $4^{\circ} \mathrm{C}$. After centrifugation for 45 minutes at $4^{\circ} \mathrm{C}$ and 3000 $g$, the precipitate was counted on a twin-head gamma counter (LKB, Finland). Assay buffer comprised $0.05 \mathrm{~mol} / 1$ tris- $\mathrm{HCl}$ pH $7 \cdot 6$, containing $0.3 \%(\mathrm{~W} / \mathrm{V})$ bovine serum albumin (RIA grade, Sigma, UK) and $0 \cdot 1 \%$ Triton X100 (Sigma, UK). Standard curves were constructed in assay buffer from a stock of the international standard for human atrial natriuretic peptide (code $85 / 669$, NIBSC, London). The antiserum was used at 1:5 of the dilution recommended by Peninsula. This produced an overall assay sensitivity of $1 \mathrm{pg} /$ tube (determined as the peptide concentration giving a $10 \%$ decrease in binding) and intra and inter assay variations of $10 \%(n=10)$ and $19 \%(n=21) \quad$ respectively. Related samples from the same patient were always included in the same extraction run and assay.

We used non-parametric tests for statistical analysis. A Wilcoxon paired analysis was performed to determine whether there was a significant decline in atrial natriuretic peptide after restoration of sinus rhythm. A MannWhitney test was used to compare plasma concentrations during tachycardia in young infants with those in older children and to compare the heart rates and duration of tachycardia in these two groups. Spearman's rank correlation coefficient was used to assess the relation between plasma atrial natriuretic peptide during tachycardia and the age of the patient, duration of tachycardia, and heart rate. The correlation between the plasma concentration and the dose of adenosine given to patients was calculated similarly. Ethical approval was obtained from our hospital ethics committee.

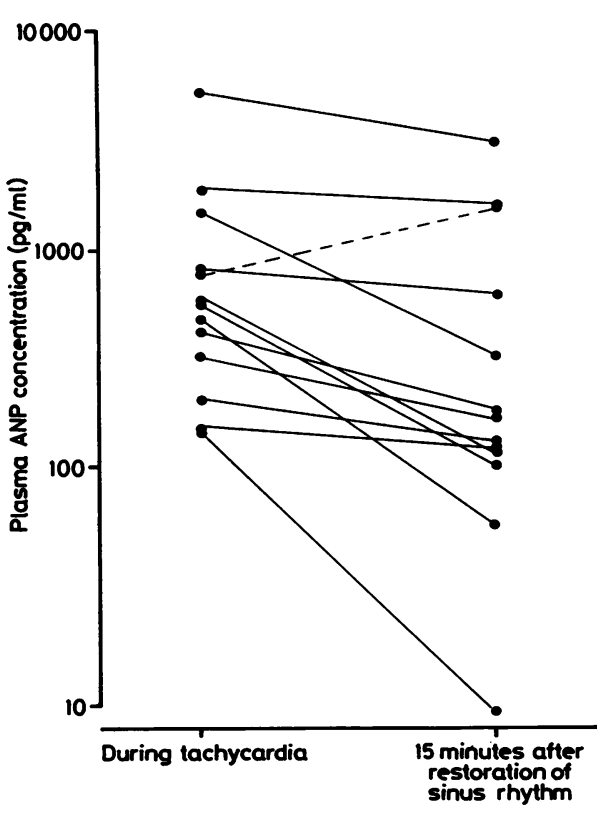

Figure 1 Changes in plasma atrial natriuretic peptide (ANP) 15 minutes after restoration of sinus rhythm in 13 children with spontaneous tachycardia.

\section{Results}

Adenosine was given in incrementally increasing doses of $0.05 \mathrm{mg} / \mathrm{kg}$ from $0.05 \mathrm{mg} / \mathrm{kg}$ to $0.3 \mathrm{mg} / \mathrm{kg}$ to all patients. Patients 4,6 , and 7 did not respond to adenosine despite maximal dosages of $0.3 \mathrm{mg} / \mathrm{kg}$. In these patients tachycardia was terminated with flecainide. After intravenous flecainide and despite restoration of sinus rhythm patient 5 became hypertensive, poorly perfused, and the cardiac failure worsened (as assessed by hepatomegaly).

Figure 1 shows the plasma concentrations of atrial natriuretic peptide for each patient both during tachycardia and after restoration of sinus rhythm. The decline in plasma concentration after the end of tachycardia was significant $(p<0.02)$. There was no significant correlation between plasma atrial natriuretic peptide during tachycardia and the duration of tachycardia. There was a weak positive correlation between heart rate and plasma concentration (0.29) and a weak negative correlation between age and plasma concentration $(-0.38)$; neither correlation was significant. When considered as a group, however, the children under 1 year of age had significantly higher plasma concentrations of atrial natriuretic peptide than the older children ( $\mathrm{p}<0.02,96.2 \%$ confidence interval from 154 to $1839 \mathrm{pg} / \mathrm{ml}$ ). Figure 2 shows the plasma concentrations of atrial natriuretic peptide during tachycardia plotted against age. There was no significant difference between either the heart rates or the duration of tachycardia of the two age groups. Blood pressure and respiratory rate did not change significantly after restoration of sinus rhythm.

There was a positive correlation between the 
Figure 2 Distribution of plasma atrial natriuretic peptide ( $A N P$ ) during tachycardia with age in 13 children.

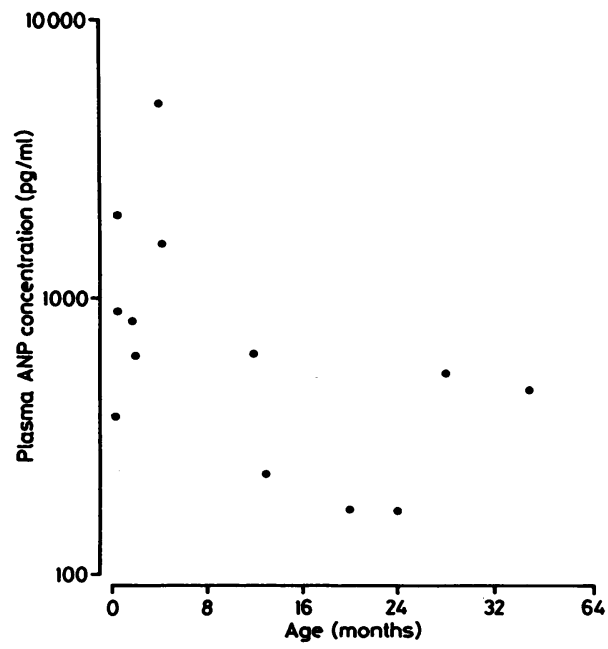

dose of adenosine used to terminate atrioventricular re-entrant tachycardia and plasma atrial natriuretic peptide during the tachycardia $(r=0.57)$. The correlation coefficient was increased ( $r=0.58)$ and was significant at the $5 \%$ level when the three patients $(4,6$, and 7 ) who were unresponsive to the maximum dose $(0.3 \mathrm{mg} / \mathrm{kg})$ of adenosine were included.

\section{Discussion}

The findings in our study accorded with the results in adults in whom there was a significant and rapid decline of plasma atrial natriuretic peptide after restoration of sinus rhythm. ${ }^{4}$ In addition, we showed that the absolute plasma concentrations during tachycardia were significantly greater in infants than in older children. Why is there a difference between the two groups? One factor may be the duration of tachycardia. Early detection of an arrhythmia is difficult in the very young patient and the longer duration of tachycardia may lead to continued release of atrial natriuretic peptide. We do not believe this to be the case because our younger patients did not have a significantly longer period of tachycardia than the older children. This seems to support animal work that showed a decline in plasma concentrations of the peptide during sustained rapid cardiac pacing. ${ }^{13}$

Others suggested that the high tachycardia rate may be a factor in the increased release of the peptide. ${ }^{14}$ While it is true that the atrioventricular node is capable of faster conduction in infancy, ${ }^{15}$ we found no significant difference between tachycardia rates in infancy and early childhood.

A possible explanation for the significantly higher concentrations in our younger patients is that they have greater stores of atrial natriuretic peptide. Plasma concentrations are high in healthy newborn infants and they decrease during the first week of life. ${ }^{16}$ We found no significant correlation between plasma concentration and age per se, however; and only when the infants were considered as a group did they have significantly higher concentrations than the older children.

The young infant often presents in cardiac failure as a result of tachycardia. ${ }^{11}$ Five of the seven infants in our study were in heart failure at presentation, but none of the older children was. The plasma concentration of atrial natriuretic peptide increased in adult patients with congestive cardiac failure and the plasma concentration seemed to be directly related to right atrial pressure. ${ }^{1718}$ The effect of heart failure on plasma concentrations of atrial natriuretic peptide was further illustrated by our findings in one infant in whom cardiovascular collapse and worsening cardiac failure occurred after intravenous flecainide, probably because of the negative inotropic effect of the drug. ${ }^{19}$ In this patient, plasma atrial natriuretic peptide increased despite restoration of sinus rhythm. We believe that the increased incidence of heart failure in the infants we studied was the likely cause of their raised plasma concentrations of atrial natriuretic peptide.

At our hospital, adenosine is used to treat reentrant tachycardia in children. ${ }^{20} \mathrm{We}$ found the dose given correlated significantly with the plasma concentration of the peptide. This may merely represent the finding that the children with the highest concentrations of the peptide are those with the more severe cardiac failure and therefore with the greatest sympathetic drive to their atrioventricular node. Alternatively, there may be a direct interaction between adenosine and atrial natriuretic peptide. Further studies are needed to clarify this.

The changes we have shown in plasma atrial natriuretic peptide define the pattern of release in childhood tachycardias and reflect the differing response of the infant heart to disturbances of rhythm. Atrial natriuretic peptide is beginning to be used as a therapeutic agent in adults. $^{21} 22$ Before it is used in children, a clearer understanding of the pathophysiology is essential.

We thank Action Research for the Crippled Child and BAT Ltd for grant support.

1 Rascher W, Tulassay T, Lang RF. Atrial natriuretic peptide in plasma of volume loaded children with chronic renal in plasma of volume loaded

2 Schiebinger RJ, Linden J. The influence of resting tension on immunoreactive atrial natriuretic peptide secretion by rat atria superfused in vivo. Circ Res 1986;59:105-9.

3 Crozier IG, Ikram H, Nicholls MG, Espiner EA, Yandle TG. Atrial natriuretic peptide in spontaneous tachycardias. Br Heart J 1987;58:96-100

4 Oliver JR, Twidale N, Lakin C, Cain M, Tonkin AM Plasma atrial natriuretic polypeptide concentrations during and after reversion of paroxysmal supraventricular tachycardias. Br Heart $J$ 1988;59:458-62.

5 Anderson JV, Gibbs JSR, Woodruff PWR, Greco C Rowland E, Bloom SR.'The plasma atrial natriuretic peptide response to treatment of acute cardiac failure, peptide response to treatment of acute cardiac failure, entrant tachycardia in man. $J$ Hypertens 1986;4(suppl 2): entrant tach

6 Fromer M, Razi M, Dubul M, Bichet D, Shenasa M. Effect of induced ventricular tachycardia on atrial natriuretic

peptide in humans. J Am Coll Cardiol 1988;12:1395-9.
7 Walsh KP, Williams TDM, Spiteri C, Pitts E, Lightman SL, Sutton R. Mechanism of atrial natriuretic peptide release during

8 Tsai RS, Yamaji T, Ishibashi $\mathbf{M}$, et al. Atrial natriuretic 
peptide during supraventricular tachycardia and relation to haemodynamic changes and renal function. $A m$ Cardiol 1988;61:1260-4.

9 Kirkpatrick SE, Nabiloff J, Pitlick PT, et al. The influence of post stimulation potentiation and heart rate on the fetal lamb heart. Am J Physiol 1975;229:318-23.

10 Rudolph AM, Heyman MA. Cardiac output in the fetal lamb: the effects of spontaneous and induced change of lamb: the effects of spontaneous and induced change of heart rate on right and left

11 Gikonyo BM, Dunnigan A, Benson DW. Cardiovascular collapse in infants: association with paroxysmal atria tachycardia. Pediatrics 1985;76:922-6.

12 Yandle TG, Espiner EA, Nicholls MG, Duff H. Radioimmunoassay and characterization of atrial natriuretic peptide in human plasma. J Clin Endocrinol Metab 1986;63:72-9.

13 Walsh KP, Williams TDM, Wilder R, Pitts E, Lightman $S L$, Sutton $R$. Decline of atrial natriuretic peptide release in dogs during sustained rapid cardiac pacing. Clin $S c i$ 1988;74:567-70.

14 Ellengbogen KA, Mohanty PK, Sowers JR, Walsh M Thames MD. Atrial natriuretic factor release is enhanced by incremental atrial pacing. Am Heart $J$ 1988;116: by increm

15 Ward DE, Camm AJ. Clinical electrophysiological methods In: Clinical electrophysiology of the heart. London: Edward Arnold, 1987:21
16 Ito Y, Matsumoto T, Ohbu K, et al. Concentrations of human atrial natriuretic peptide in the cord blood and the plasma of the newborn. Acta Paediatr Scand 1988;77: 76-8.

17 Hara H, Ogihari T, Nakamuru M, Rakugi H, Tateyamah H. Changes in the levels of plasma atrial natriuretic peptide, haemodynamic measurements and the levels of vasoactive hormones during the clinical course of congestive heart failure. Clin Cardiol 1988;11:743-7.

18 Creager MA, Hirsh AT, Nabel EG, Cutler S, Colucci WS, Ozau VJ. Responsiveness of atrial natriuretic factor to reduction in right atrial pressure in patients with congestive cardiac failure. $J \mathrm{Am}$ Coll Cardiol 1988;11:1191-8.

19 Hopkins J, Kvam D, Singh BN. Haemodynamic effects of intravenous flecainide relative to the level of ventricular function in patients with coronary artery disease. $\mathrm{Am}$ Heart $J$ 1985;109:41-4.

20 Clarke B, Till JA, Rowland E, Ward DE, Barnes PJ, Shinebourne EA. Rapid termination of supraventricular tachycardia in children by adenosine. Lancet 1987; i: 299-301.

21 Crozier IG, Nicholls MG, Ikram H, Espiner EA, Gomez HJ, Warner NJ. Haemodynamic effects of atrial peptide infusion in heart failure. Lancet 1986;ii:1242-5.

22 Saito Y, Nakao K, Nishimura K, et al. Clinical application of atrial natriuretic polypeptide in patients with congestive heart failure: beneficial effects on left ventricular function Circulation 1987;76:115-24. 